\title{
Polymorphisms of the Homologous Recombination Gene RAD51 in Keratoconus and Fuchs Endothelial Corneal Dystrophy
}

\author{
Ewelina Synowiec, ${ }^{1}$ Katarzyna A. Wojcik, ${ }^{1}$ Justyna Izdebska, ${ }^{2}$ Ewelina Binczyk, ${ }^{2}$ \\ Janusz Blasiak, ${ }^{1}$ Jerzy Szaflik, ${ }^{2}$ and Jacek P. Szaflik ${ }^{2}$ \\ ${ }^{1}$ Department of Molecular Genetics, University of Lodz, Pomorska 141/143, 90-236 Lodz, Poland \\ ${ }^{2}$ Department of Ophthalmology, Medical University of Warsaw and Samodzielny Publiczny Kliniczny Szpital Okulistyczny, \\ Sierakowskiego 13, 03-710 Warsaw, Poland \\ Correspondence should be addressed to Jacek P. Szaflik; szaflik@ophthalmology.pl
}

Received 11 July 2013; Accepted 28 August 2013

Academic Editor: Yi-Chia Huang

Copyright ( 2013 Ewelina Synowiec et al. This is an open access article distributed under the Creative Commons Attribution License, which permits unrestricted use, distribution, and reproduction in any medium, provided the original work is properly cited.

\begin{abstract}
Purpose. We investigated the association between genotypes and haplotypes of the c.-61G $>$ T (rs 1801320) and c.-98G >C (rs 1801321) polymorphisms of the RAD51 gene and the occurrence of keratoconus (KC) and Fuchs endothelial corneal dystrophy (FECD) in dependence on some environmental factors. Methods. The polymorphisms were genotyped in peripheral blood lymphocytes of $100 \mathrm{KC}$ and $100 \mathrm{FECD}$ patients as well as 150 controls with PCR-RFLP. Results. The G/T genotype of the c. $-61 \mathrm{G}>\mathrm{T}$ polymorphism was associated with significantly increased frequency occurrence of KC (crude OR 2.99, 95\% CI 1.75-5.13). On the other hand, the G/G genotype of this polymorphism was positively correlated with a decreased occurrence of this disease (crude OR 0.52, 95\% CI 0.31-0.88). We did not find any correlation between genotypes/alleles of the c.-98G $>$ C polymorphism and the occurrence of KC. We also found that the $\mathrm{G} / \mathrm{G}$ genotype and $\mathrm{G}$ allele of the c.-98G $>\mathrm{C}$ polymorphism had a protective effect against FECD (crude OR 0.51, 95\% CI 0.28-0.92; crude OR 0.53, 95\% CI 0.30-0.92, resp.), while the G/C genotype and the C allele increased FECD occurrence (crude OR 1.85, 95\% CI 1.01-3.36; crude OR 1.90, 95\% CI 1.09-3.29, resp.). Conclusions. The c.-61T/T and c.-98G>C polymorphisms of the RAD51 gene may have a role in the KC and FECD pathogenesis and can be considered as markers in these diseases.
\end{abstract}

\section{Introduction}

Keratoconus (KC, MIM no. 148300) is a chronic, noninflammatory, degenerative disease of the cornea and can lead to severe visual impairment or blindness. $\mathrm{KC}$ is a leading cause of corneal transplantation in Western countries [1]. It is estimated that in $\sim 20 \%$ of cases, it progresses to the point of legal blindness and then can be treated only by corneal transplantation. KC typically progresses until the third to fourth decade of life [2]. This disease is observed in all ethnic groups with no female or male predominance [3]. It was found that the incidence of $\mathrm{KC}$ in Asians is 25 per 100000 (1 in 4000) per year, compared with 3.3 per 100000 ( 1 in 30 $000)$ per year in Caucasians $(P<0.001)[4]$. Although the exact pathogenesis of $\mathrm{KC}$ is unclear, genetic, environmental, and behavioral factors as well as interaction between them may be involved. Genetic factors include familial inheritance, discordance between dizygotic twins, and their association with other genetic disorders. The familial nature of $\mathrm{KC}$ has been reported in several studies; the prevalence of $\mathrm{KC}$ in first degree relatives is $3.34 \%$, which is $15-67$ times higher than that of the general population [5]. In such cases, both autosomal dominant and recessive patterns of inheritance have been described [5]. KC is also associated with genetic disorders, such as Leber's congenital amaurosis [6], Down syndrome [7], Ehlers-Danlos syndrome [8], osteogenesis imperfecta [9], and Turner syndrome [10]. It occurs with a higher concordance rate of the trait in monozygotic than in dizygotic twins [11]. Genome-wide linkage analyses have identified several chromosomal regions/gene loci that may be 
associated with $\mathrm{KC}$. To date, chromosomal regions 20p11-q1, 16q22.3-3-q23.1,3p14-q13, 2p24, and 15q22.23-24 as well as the VSX1 (visual system homeobox 1) gene on 20p11.2 and the SOD1 (superoxide dismutase 1) gene on 21q22.11 have been implicated in KC pathogenesis [12-15]. These findings show a heterogeneous and complex genetic nature of $\mathrm{KC}$. The disease may be also associated with various environmental factors, including hard contact lenses, chronic eye rubbing, and atopy of the eye $[16,17]$.

Fuchs endothelial corneal dystrophy (FECD, MIM no. $136800)$ is a degenerative, slowly progressive corneal disease leading to blindness in its advanced stage [18]. It is characterized by an accelerated loss of corneal endothelial cells, morphological changes in the cornea, and increased deposition of extracellular matrix at the Descemet membrane (a collagen-rich basal lamina) secreted by corneal endothelium, called corneal guttae $[19,20]$. These changes in the structure of the cornea block ion transport and solute barrier functions in the endothelial layer, resulting in the progressive dysfunction of the corneal endothelium [21, 22]. The endothelial dysfunction and loss of corneal endothelial cells lead to corneal decompensation and impaired vision [23]. Based on its clinical and pathologic features, FECD is classified into two forms: early-onset FECD and most typical late-onset form of this disease, which can lead to visual loss [24, 25]. FECD is considered as a disease of aging that typically appears over the age of 50 years. Generally, FECD begins in the 5 th decade of life and can progress slowly over the next 2 to 3 decades [26]. This disease occurs predominantly in women at a ratio $2.5-3: 1$ [18], who comprise approximately $75 \%$ of cases [27]. Several reports have shown that FECD is often inherited as an autosomal dominant trait [28-30], and 50\% of affected patients are estimated to show a familial clustering [31]. At present, the only treatment modality to restore lost vision is corneal transplantation in the form of penetrating keratoplasty or Descemet's stripping endothelial keratoplasty. The disease is one of the most common indications for corneal transplantation performed in the USA [22]. Despite these findings, the pathogenesis of FECD remains poorly understood. Some evidence suggests that FECD may develop independently of systemic or environmental factors [29, 31]. Therefore, understanding genetic risk factors that cause the disease is crucial for establishing strategies to prevent and treat it. The first gene to be causally linked with FECD was COL8A2. This gene is located on chromosome 1 (1p34.3p32) and encodes the alpha 2 chain of type VIII collagen, a major component of Descemet membrane. Two missense mutations, p.L450W and p.Q455V/Q455 K, have been identified in early-onset form multigenerational families with FECD [32-34] and in atypical sporadic FECD cases [34]. Several genome-wild linkage scans in large multigenerational families have mapped late-onset FECD susceptibility loci on chromosomes 13 (FCD1), 18 (FCD2), 5 (FCD3), and 9 (FCD4) [35-37].

A growing body of evidence suggests that oxidative stress may play an important role in the pathogenesis of $\mathrm{KC}$ and FECD [38-45]. The cornea is a transparent, avascular structure of the eye that is exposed to a wide spectrum of light, including the ultraviolet (UV) radiation. UV exposure is a well-characterized environmental stress factor that generates free radicals and reactive oxygen species (ROS), harmful to most cells and tissues [46]. Since the cornea is the first target of UV-light entering the eye, it is especially susceptible to damage from ROS. An excess of ROS may induce mutations, cancer, or cell death [47]. In normal conditions, the cornea has natural antioxidant enzymes, such as superoxide dismutase, catalase, glutathione reductase, and glutathione peroxidase that eliminate ROS [48]. On the other hand, in disease state, the cornea displays an altered activity of antioxidant enzymes, accumulation of ROS, and mitochondrial DNA damage [39, 41, 42, 49].

ROS can cause a variety of DNA damage, including DNA single and double strand breaks (DSBs) and DNA base modifications. Therefore efficient repair of ROS-induced DNA damage is important for preventing mutations and maintaining the stability of the genome. It has been demonstrated that DNA damage has been implicated as a causative factor in a wide variety of degenerative diseases, cancer, and premature aging [50-54]. The most dangerous and lethal types of DNA damage are DSBs, which if left unrepaired can result in permanent cell cycle arrest, apoptosis, or mitotic cell death caused by the loss of genomic material [55]; if misrepaired, they can lead to cancer and other disorders through translocations, inversions, or deletions [56, 57]. In mammalian cells, DSBs can be repaired by nonhomologous end joining (NHEJ) or homologous recombination (HRR) pathways. It was shown that single-nucleotide polymorphisms (SNPs) in DNA repair genes could modulate individual DNA repair capacity and therefore affected individual genetic susceptibility to cancer and other disorders, including eye diseases [42, 58-63].

Several case-control studies have confirmed the association between genetic polymorphisms or mutations and corneal diseases [22, 27, 64-69]. We hypothesize that genetic variations in the RAD51 gene may also contribute to the development of KC and FECD. The RAD51 protein encoded by this gene is the central protein involved in homologous recombination and repair of DSBs in humans. In the present work we checked whether two polymorphisms, c. $-61 \mathrm{G}>\mathrm{T}$ and c. $-98 \mathrm{G}>\mathrm{C}$, of the RAD51 gene were associated with KC/FECD occurrence and whether this association was modulated by some demographic and potential risk factors for KC/FECD. Both polymorphisms are SNPs located in the $5^{\prime}$ untranslated region ( $5^{\prime}$ UTR) of the gene. These SNPs have been chosen as they were reported to be associated with altered gene transcription [70].

\section{Materials and Methods}

2.1. Ethics. The study design was approved by the Bioethics Committee of the Medical University of Warsaw, and each patient or control individual enrolled in this study gave a written informed consent and approval form for genetic analysis in compliance with the Helsinki declaration.

2.2. Study Population and Sample Collection. The study population comprised 100 patients with KC, 100 patients with FECD, and 150 individuals with healthy corneas (controls). 
TABLE 1: Characteristics of KC and FECD patients and controls enrolled in this study.

\begin{tabular}{|c|c|c|c|c|c|c|c|c|}
\hline \multirow{2}{*}{ Feature } & \multirow{2}{*}{\multicolumn{2}{|c|}{$\begin{array}{ll}\text { Controls }(n=150) \\
\text { Number } \quad \text { Frequency }\end{array}$}} & \multicolumn{2}{|c|}{$\mathrm{KC}(n=100)$} & \multirow{2}{*}{$P$} & \multicolumn{2}{|c|}{$\operatorname{FECD}(n=100)$} & \multirow{2}{*}{$P$} \\
\hline & & & Number & Frequency & & Number & Frequency & \\
\hline \multicolumn{9}{|l|}{ Sex } \\
\hline females & 96 & 0.96 & 30 & 0.30 & $<0.001$ & 73 & 0.73 & 0.176 \\
\hline males & 54 & 0.54 & 70 & 0.70 & & 27 & 0.27 & \\
\hline \multicolumn{9}{|l|}{ Age } \\
\hline Mean \pm SD & $67.02 \pm 16.83$ & & $36.54 \pm 11.12$ & & $<0.001^{*}$ & $71.76 \pm 9.25$ & & $<0.001^{*}$ \\
\hline Range & $20-100$ & & $20-63$ & & & $47-91$ & & \\
\hline \multicolumn{9}{|l|}{ Smoking } \\
\hline yes (current/former) & 20 & 0.13 & 24 & 0.24 & 0.045 & 32 & 0.32 & 0.0007 \\
\hline never & 130 & 0.87 & 76 & 0.76 & & 68 & 0.68 & \\
\hline \multicolumn{9}{|l|}{$\mathrm{KC} / \mathrm{FECD}$ in family } \\
\hline yes & 3 & 0.02 & 9 & 0.09 & 0.0254 & 10 & 0.10 & 0.0124 \\
\hline no & 147 & 0.98 & 91 & 0.91 & & 90 & 0.90 & \\
\hline \multicolumn{9}{|l|}{ BMI } \\
\hline$\leq 25$ & 64 & 0.44 & 43 & 0.43 & 0.993 & 40 & 0.40 & 0.838 \\
\hline $25-30$ & 46 & 0.31 & 32 & 0.32 & & 31 & 0.31 & \\
\hline$\geq 30$ & 37 & 0.25 & 25 & 0.25 & & 28 & 0.28 & \\
\hline \multicolumn{9}{|l|}{ Visual impairment } \\
\hline yes & 44 & 0.29 & 67 & 0.67 & $<0.001$ & 52 & 0.52 & $<0.001$ \\
\hline no & 106 & 0.71 & 33 & 0.33 & & 48 & 0.48 & \\
\hline \multicolumn{9}{|l|}{ Allergies } \\
\hline yes & 23 & 0.15 & 23 & 0.23 & 0.172 & 14 & 0.14 & 0.913 \\
\hline no & 127 & 0.85 & 77 & 0.77 & & 86 & 0.86 & \\
\hline
\end{tabular}

$P$ values for a two-sided $\chi^{2}$-test; ${ }^{*} P$ values for $t$-test. $P<0.05$ are in bold.

All patients and controls were examined in the Department of Ophthalmology, Medical University of Warsaw (Warsaw, Poland). Medical history was obtained from all subjects, and no one reported any genetic disease.

The diagnosis of KC was based on clinical signs and topographical and pachymetric parameters on TMS corneal topography and Orbscan examinations $[2,71,72]$. The map patterns were carefully interpreted manually in all cases. Patients underwent ophthalmic examination, including bestcorrected visual acuity, intraocular pressure, slit lamp examination, fundus examination, corneal topography (TMS4, Tomey, Nagoya, Japan), Orbscan corneal topographical, and pachymetrical maps (Orbscan IIz, Bausch \& Lomb, USA).

The diagnosis of FECD was based on clinical signs on the slit lamp examination (occurrence of endothelial guttae, corneal edema) and in all the cases was confirmed by the presence of specific lesions, polymegathism, and pleomorphism of the endothelial cells in in vivo confocal microscopy (IVCM) examination [73, 74]. Patients underwent ophthalmic examination, including best-corrected visual acuity, intraocular pressure, slit lamp examination, fundus examination, IVCM, and anterior segment optical coherence tomography including pachymetry maps (AS-OCT). The IVCM was performed by white light scanning slit confocal microscopy system (ConfoScan 3 or ConfoScan 4, Nidek Techologies, Padova, Italy). The AS-OCT was performed by Swept Source Anterior Segment Casia OCT (Tomey, Nagoya, Japan).
The control subjects had no clinical evidence of FECD/ $\mathrm{KC}$ and presented with healthy corneal endothelium on IVCM and normal corneal topography and pachymetry.

Five $\mathrm{mL}$ of venous blood was collected from each individual enrolled in this study into EDTA-containing tubes, coded and stored at $-20^{\circ} \mathrm{C}$ until further use.

2.3. Interviews. All participants were interviewed using a structural questionnaire to determine demographic and potential risk factors for KC and FECD. Study cases and controls provided information on their age, lifestyle habits including smoking, body mass index (BMI), allergy, cooccurrence of visual impairment (hyperopia, astigmatism, and myopia), and family history among 1st degree relatives for $\mathrm{KC}$ or FECD. Smoking was categorized due to current, former, or never smokers. Characteristics of patients and controls are presented in Table 1. All individuals employed in our research were unrelated.

2.4. SNP Selection and Primers Design. We searched the public domain of the National Center for Biotechnology Information the Single Nucleotide Polymorphisms database (NCBI dbSNP) at http://www.ncbi.nlm.nih.gov/snp to identify potentially functional polymorphisms in the DNA repair genes. We chose to genotype the c.-61G $>\mathrm{T}$ (rs1801321) and the c.-98G >C (rs1801320) polymorphisms of the RAD51 gene 
with a minor allele frequency (MAF) 0.467 and 0.067 in European population, respectively (submitter population ID: HapMap-CEU for both; http://www.ncbi.nlm.nih.gov/snp). Primers were designed according to the published nucleotide sequence in ENSEMBL database (gene ID ENSG00000051180) and using Primer3 software (http://frodo.wi .mit.edu/).

We chose polymorphisms of the known distribution in the European population. SNPs selection favored those with a minor allele frequency not less than $5 \%$. Our choice was mainly determined by a potential biological significance of the polymorphisms following from their location. Both SNPs are located in the $5^{\prime}$ UTR of the gene and may be associated with altered gene transcription.

2.5. DNA Extraction. Genomic DNA was extracted from venous blood by using the commercially available AxyPrep Blood Genomic DNA Miniprep Kit (Axygen Biosciences, Union City, CA, USA), according to the manufacturer's instructions. DNA was directly isolated from the white blood cells. DNA purity and concentration were determined by comparing the absorbance at 260 and $280 \mathrm{~nm}$. The purified genomic DNA was stored in TE buffer $(5 \mathrm{mM}$ Tris- $\mathrm{HCl}$, $0.1 \mathrm{mM}$ EDTA, $\mathrm{pH} 8.5$ ), at $-20^{\circ} \mathrm{C}$ until further analysis.

2.6. SNP Genotyping. The c. $-61 \mathrm{G}>\mathrm{T}$ and c. $-98 \mathrm{G}>\mathrm{C}$ polymorphisms were genotyped by polymerase chain reactionrestriction fragment length polymorphism (PCR-RFLP) method. The total reaction volume of $20 \mu \mathrm{L}$ contained $50 \mathrm{ng}$ of genomic DNA, $1 \times$ Kapa Taq Ready Mix containing KapaTag DNA polymerase $(0.025 \mathrm{U} / \mu \mathrm{L})$, reaction buffer with $\mathrm{MgCl}_{2}$ and $0.2 \mathrm{mM}$ each dNTP (Kapa Biosystems, Woburn, MA, USA), and $0.25 \mu \mathrm{M}$ of each primer (Metabion, Martinsried, Germany). 131-bp length fragments containing two SNPs were amplified using the following primers: forward $5^{\prime}$ TGG GAA CTG CAA CTC ATC TGG- $3^{\prime}$ and reverse $5^{\prime}$-GCT CCG ACT CCC CGC CGG-3'. The PCR profile consisted of an initial denaturation step for $5 \mathrm{~min}$ at $95^{\circ} \mathrm{C}, 30$ cycles at $95^{\circ} \mathrm{C}$ for $30 \mathrm{~s}, 30 \mathrm{~s}$ at $65^{\circ} \mathrm{C}$ annealing temperature and $60 \mathrm{~s}$ at $72^{\circ} \mathrm{C}$, and the final extension step for $5 \mathrm{~min}$ at $72^{\circ} \mathrm{C}$. The amplified $131 \mathrm{bp}$ fragments were analyzed on a $3 \%$ agarose gel and separated into two groups. One group was digested with $2 \mathrm{U}$ of NgoMIV restriction endonuclease (New England BioLabs, Beverly, MA, USA) in a final volume of $15 \mu \mathrm{L}$ for $16 \mathrm{~h}$ at $37^{\circ} \mathrm{C}$ to analyse c.- $61 \mathrm{G}>\mathrm{T}$ polymorphism, while the second group was digested with $2 \mathrm{U}$ of $M v a \mathrm{I}$ (BstNI) restriction endonuclease (Fermentas, Hanover, MD, USA) to analyse c. $-98 \mathrm{G}>\mathrm{C}$ polymorphisms under the same conditions. The G/G genotype of the c.-61G $>$ T polymorphism produced two fragments (110 and $21 \mathrm{bp}$ ), whereas the G/T genotype yielded three fragments $(131,110$, and $21 \mathrm{bp})$, and the homozygote $\mathrm{T} / \mathrm{T}$ resulted in one $131 \mathrm{bp}$ fragment. In the case of the c.-98G>C polymorphism, the $\mathrm{G} / \mathrm{G}$ genotype produced two fragments (71 and $60 \mathrm{bp}$ ) and the $\mathrm{C} / \mathrm{C}$ genotype only one fragments, while the heterozygote $\mathrm{G} / \mathrm{C}$ displayed all three fragments $(131,71$ and $60 \mathrm{bp})$. After digestion, the reaction mixture was subjected to electrophoresis on an $8 \%$ polyacrylamide gel and visualized by ethidium bromide staining using a GeneRuler

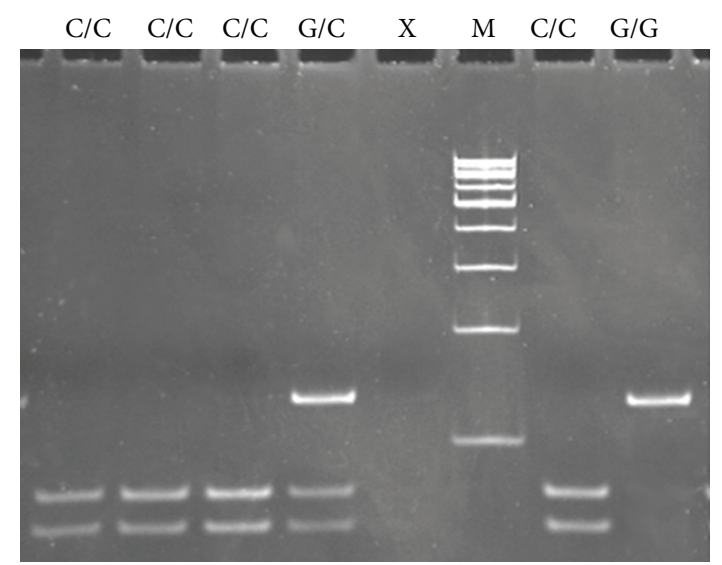

FIGURE 1: Genotyping of the RAD51- c.-98G>C (rs1801320) polymorphism. Genotypes are indicated in the upper part of the picture. Lane $\mathrm{M}$ shows GeneRuler 100 bp molecular length marker; lane X shows a negative control-reaction mixture without target DNA.
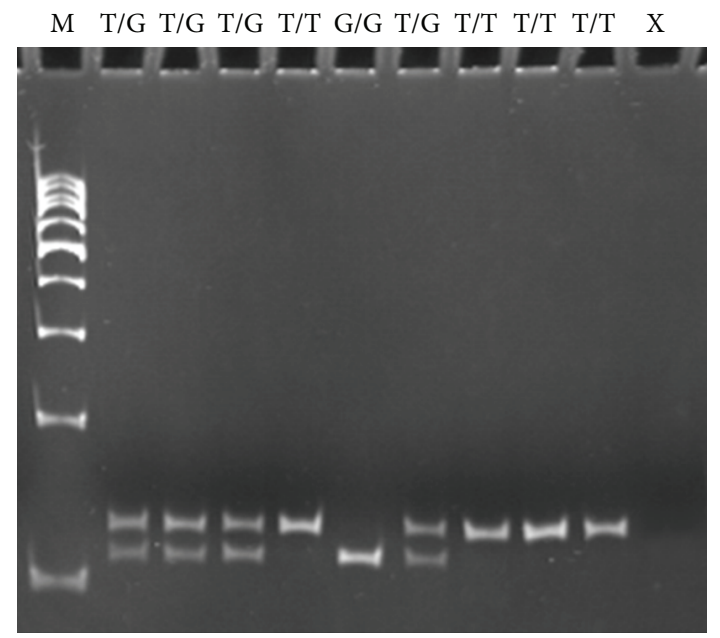

FIGURE 2: Genotyping of the RAD51- c.-61G>T (rs1801321) polymorphism. Genotypes are indicated in the upper part of the picture. Lane $\mathrm{M}$ shows GeneRuler 100 bp molecular length marker; lane X shows a negative control-reaction mixture without target DNA.

100 bp (Fermentas, Hanover, MD, USA) as a molecular mass marker. Representative gels for these polymorphisms are presented in Figures 1 and 2.

All PCR amplifications were conducted in a C1000 Thermal Cycler (Bio-Rad Laboratories, Hercules, CA, USA). Positive and negative (no template) controls were included in all sets. For quality control, $10 \%$ of samples were randomly genotyped again, and the results were $100 \%$ concordant.

2.7. Statistical Analysis. The statistical analyses were carried out with the SigmaPlot version 11.0 (Systat Software, Inc., San Jose, CA, USA), statistical software package. To compare the distributions of demographic variables and potential risk factors between patients and controls, chi-square $\left(\chi^{2}\right)$ test was used. Hardy-Weinberg equilibrium was checked using $\chi^{2}$ test to compare the observed genotype frequencies with 
TABLE 2: Distribution of genotypes and alleles of the c.-61G>T and c.-98G>C polymorphisms of the RAD51 gene and odds ratio (OR) with $95 \%$ confidence interval ( $95 \% \mathrm{CI})$ in patients with $\mathrm{KC}$ and controls.

\begin{tabular}{|c|c|c|c|c|c|c|c|c|}
\hline \multirow{2}{*}{$\begin{array}{l}\text { Genotype/allele } \\
\text { polymorphisms }\end{array}$} & \multicolumn{2}{|c|}{ Controls $(n=150)$} & \multicolumn{2}{|c|}{$\mathrm{KC}(n=100)$} & \multirow{2}{*}{ Crude OR (95\% CI) } & \multirow{2}{*}{$P$} & \multirow{2}{*}{ Adjusted $\mathrm{OR}^{\mathrm{a}}(95 \% \mathrm{CI})$} & \multirow{2}{*}{$P$} \\
\hline & Number & Frequency & Number & Frequency & & & & \\
\hline \multicolumn{9}{|c|}{ c. $-61 G>T$} \\
\hline $\mathrm{G} / \mathrm{G}$ & 76 & 0.51 & 35 & 0.35 & $0.52(0.31-0.88)$ & 0.015 & $0.54(0.31-0.98)$ & 0.043 \\
\hline $\mathrm{G} / \mathrm{T}$ & 39 & 0.26 & 51 & 0.51 & $2.99(1.75-5.13)$ & $<0.001$ & $2.54(1.41-4.58)$ & 0.002 \\
\hline $\mathrm{T} / \mathrm{T}$ & 35 & 0.23 & 14 & 0.14 & $0.53(0.27-1.06)$ & 0.071 & $0.65(0.31-1.36)$ & 0.251 \\
\hline \multicolumn{9}{|c|}{$\chi^{2}=16.400 ; P=0.0003$} \\
\hline G & 191 & 0.64 & 121 & 0.60 & $0.75(0.47-1.22)$ & 0.563 & $0.89(0.61-1.30)$ & 0.530 \\
\hline $\mathrm{T}$ & 109 & 0.36 & 79 & 0.40 & $1.10(0.79-1.54)$ & 0.563 & $1.14(0.79-1.65)$ & 0.477 \\
\hline \multicolumn{9}{|c|}{ c. $-98 \mathrm{G}>\mathrm{C}$} \\
\hline $\mathrm{G} / \mathrm{G}$ & 122 & 0.81 & 80 & 0.80 & $0.92(0.48-1.74)$ & 0.793 & $0.82(0.40-8.33)$ & 0.596 \\
\hline $\mathrm{G} / \mathrm{C}$ & 27 & 0.18 & 19 & 0.19 & $1.06(0.55-2.03)$ & 0.861 & $1.18(0.56-2.46)$ & 0.665 \\
\hline $\mathrm{C} / \mathrm{C}$ & 1 & 0.01 & 1 & 0.01 & $1.51(0.09-24.33)$ & 0.773 & $1.79(0.09-35.84)$ & 0.703 \\
\hline \multicolumn{9}{|c|}{$\chi^{2}=0.129 ; P=0.9375$} \\
\hline G & 271 & 0.90 & 179 & 0.90 & $0.91(0.50-1.66)$ & 0.758 & $0.82(0.42-1.61)$ & 0.562 \\
\hline $\mathrm{C}$ & 29 & 0.10 & 21 & 0.10 & $1.09(0.60-2.00)$ & 0.758 & $1.22(0.62-2.39)$ & 0.562 \\
\hline
\end{tabular}

$P<0.05$ along with corresponding ORs are in bold; ${ }^{a} \mathrm{OR}$ adjusted for cooccurrence of visual impairment, smoking, and family history for KC.

the expected frequencies among the case and control subjects. The $\chi^{2}$ analysis was also used to test the significance of the differences between distributions of genotypes and alleles in $\mathrm{KC} / \mathrm{FECD}$ patients and controls. The association between case-control status and each polymorphism, measured by the odds ratio (OR) and its corresponding 95\% confidence interval (CI), was estimated using an unconditional multiple logistic regression model, both with and without adjustment for cooccurrence of visual, smoking, and family status of KC/FECD.

\section{Results}

The PCR-RFLP analyses were successful for all 250 DNA samples (100 KC/FECD patients and $150 \mathrm{KC} / \mathrm{FECD}$ free controls).

3.1. Characteristics of the Study Subjects. Table 1 presents demographic and potential risk factors for KC and FECD of the study patients and controls. The mean \pm SD age for $\mathrm{KC}$ patients were $36.54 \pm 11.12$ (range 20-63), $71.76 \pm 9.25$ (range 47-91) for FECD patients, and 67.02 \pm 16.83 (range 20-100) for controls. Moreover, there were significantly more subjects with positive family history for KC and FECD (1st degree relatives) among the patients in comparison to controls (9\% and $10 \%$ versus $2 \%, P<0.05)$. We demonstrated significant differences between distribution of family history for $\mathrm{KC} / \mathrm{FECD}$ (positive versus negative family history), smoking (yes versus never), and cooccurrence of visual impairment (yes versus no) among patients and controls. These parameters were further adjusted in multivariate logistic regression model for possible confounding factors of the main effect of the SNPs.

3.2. The c.-61G>T and c.-98>C Polymorphisms of the RAD51 Gene and KC Occurrence. The genotype and allele distributions of the c.-61G $>\mathrm{T}$ polymorphism of the RAD51 gene in KC patients and controls are presented in Table 2. The observed genotypes frequencies did not differ significantly from Hardy-Weinberg equilibrium $(P>0.05$, data not shown) for each group. The difference in the frequency distributions of genotypes of the c.-61G $>$ T polymorphism between the cases and controls was statistically significant $(P<0.05)$. The presence of the G/T genotype significantly increased the occurrence of KC (crude OR 2.99, 95\% CI 1.75-5.13). On the other hand, the G/G genotype decreased it (crude OR 0.52, 95\% CI 0.31-0.88). We did not find any correlation between genotypes/alleles of the other polymorphism and KC occurrence.

3.3. The c. $-61 G>T$ and c. $-98>C$ Polymorphisms of the RAD51 Gene and FECD Occurrence. Details of genotype and allele frequencies of the c.-98G $>\mathrm{C}$ polymorphisms of the RAD51 gene and summary of statistical analysis are shown in Table 3 . There was not any difference in the frequency distributions of genotypes of the c.-98G $>C$ polymorphism between patients and controls $(P>0.05)$. The observed genotypes frequencies did not differ significantly from Hardy-Weinberg equilibrium $(P>0.05$, data not shown) for each group. The presence of the T/T genotype and the $\mathrm{T}$ allele of the c.-61G>T polymorphism was associated with a decreased occurrence of KC (crude OR 0.41, 95\% CI 0.19-0.84; OR 0.50, 95\% CI 0.360.69 , resp.), but on the other hand the $\mathrm{G} / \mathrm{T}$ genotype increased it (crude OR 2.50, 95\% CI 1.46-4.28). In the case of the c.$98 \mathrm{G}>\mathrm{C}$ polymorphism, we found that the $\mathrm{G} / \mathrm{G}$ genotype and $\mathrm{G}$ allele were associated with a protective effect (crude OR 0.51 , $95 \%$ CI $0.28-0.92$; crude OR 0.53 , 95\% CI $0.30-0.92$, resp.), while the $\mathrm{G} / \mathrm{C}$ genotype and the $\mathrm{C}$ allele increased FECD occurrence (crude OR 1.85, 95\% CI 1.01-3.36; crude OR 1.90, 95\% CI 1.09-3.29). 
TABLE 3: Distribution of genotypes and alleles of the c.-61G>T and c.-98G $>$ C polymorphisms of the RAD51 gene and odds ratio (OR) with $95 \%$ confidence interval ( $95 \%$ CI) in patients with FECD and controls.

\begin{tabular}{|c|c|c|c|c|c|c|c|c|}
\hline \multirow{2}{*}{$\begin{array}{l}\text { Genotype/allele } \\
\text { polymorphisms }\end{array}$} & \multicolumn{2}{|c|}{ Controls $(n=150)$} & \multicolumn{2}{|c|}{$\operatorname{FECD}(n=100)$} & \multirow{2}{*}{ Crude OR $(95 \%$ CI $)$} & \multirow{2}{*}{$P$} & \multirow{2}{*}{ Adjusted $\mathrm{OR}^{\mathrm{a}}(95 \% \mathrm{CI})$} & \multirow{2}{*}{$P$} \\
\hline & Number & Frequency & Number & Frequency & & & & \\
\hline \multicolumn{9}{|c|}{ c. $-61 \mathrm{G}>\mathrm{T}$} \\
\hline $\mathrm{G} / \mathrm{G}$ & 76 & 0.51 & 42 & 0.42 & $0.71(0.42-1.17)$ & 0.179 & $0.76(0.44-1.32)$ & 0.334 \\
\hline $\mathrm{G} / \mathrm{T}$ & 39 & 0.26 & 47 & 0.47 & $2.50(1.46-4.28)$ & $<0.001$ & $2.30(1.27-4.16)$ & 0.006 \\
\hline $\mathrm{T} / \mathrm{T}$ & 35 & 0.23 & 11 & 0.11 & $0.41(0.19-0.84)$ & 0.016 & $0.44(0.19-0.98)$ & 0.045 \\
\hline \multicolumn{9}{|c|}{$\chi^{2}=13.607 ; P=0.0011$} \\
\hline G & 191 & 0.64 & 131 & 0.66 & $1.09(0.78-1.52)$ & 0.610 & $1.08(0.74-1.58)$ & 0.684 \\
\hline $\mathrm{T}$ & 109 & 0.36 & 69 & 0.34 & $0.50(0.36-0.69)$ & $<0.001$ & $0.93(0.63-1.35)$ & 0.684 \\
\hline \multicolumn{9}{|c|}{ c. $-98 \mathrm{G}>\mathrm{C}$} \\
\hline $\mathrm{G} / \mathrm{G}$ & 122 & 0.81 & 69 & 0.69 & $0.51(0.28-0.92)$ & 0.026 & $0.54(0.28-1.05)$ & 0.069 \\
\hline $\mathrm{G} / \mathrm{C}$ & 27 & 0.18 & 29 & 0.29 & $1.85(1.01-3.36)$ & 0.045 & $1.73(0.88-3.38)$ & 0.112 \\
\hline $\mathrm{C} / \mathrm{C}$ & 1 & 0.01 & 2 & 0.02 & $3.04(0.27-33.99)$ & 0.367 & $3.12(0.24-40.21)$ & 0.383 \\
\hline \multicolumn{9}{|c|}{$\chi^{2}=5.325 ; P=0.0698$} \\
\hline G & 271 & 0.90 & 167 & 0.84 & $0.53(0.30-0.92)$ & 0.023 & $0.55(0.30-1.02)$ & 0.059 \\
\hline $\mathrm{C}$ & 29 & 0.10 & 33 & 0.16 & $1.90(1.09-3.29)$ & 0.023 & $1.79(0.99-3.24)$ & 0.056 \\
\hline
\end{tabular}

$P<0.05$ along with corresponding ORs are in bold; ${ }^{a}$ OR adjusted for cooccurrence of visual impairment, smoking, and family history for FECD.

TABLE 4: Distribution of haplotypes of the c.-61G>T and c.-98G>C polymorphisms of the RAD51 gene and odds ratio (OR) with 95\% confidence interval (95\% CI) in patients with $\mathrm{KC}$ and FECD and controls.

\begin{tabular}{lcccccccccc}
\hline \multirow{2}{*}{ Haplotype } & \multicolumn{2}{c}{ Controls $(n=150)$} & \multicolumn{2}{c}{ KC $(n=100)$} & OR $(95 \%$ CI $)$ & $P$ & \multicolumn{2}{c}{ FECD $(n=100)$} & OR $(95 \%$ CI $)$ & $P$ \\
& Number & Frequency & Number & Frequency & & & & Number & Frequency & \\
\hline GG & 324 & 0.54 & 209 & 0.52 & $0.93(0.72-1.20)$ & 0.566 & 207 & 0.52 & $0.91(0.71-1.17)$ & 0.566 \\
GC & 218 & 0.36 & 149 & 0.37 & $1.04(0.80-1.35)$ & 0.588 & 127 & 0.32 & $0.82(0.62-1.07)$ & 0.588 \\
TG & 58 & 0.10 & 33 & 0.08 & $0.89(0.57-1.40)$ & 0.544 & 55 & 0.14 & $1.23(0.51-3.00)$ & 0.544 \\
TC & 0 & 0 & 9 & 0.02 & - & & 11 & 0 & - \\
\hline
\end{tabular}

3.4. Haplotypes and KC/FECD Occurrence. We also assessed the association between the occurrence of $\mathrm{KC} / \mathrm{FECD}$ and haplotypes of the c. $-61 \mathrm{G}>\mathrm{T}$ and c.-98G $>\mathrm{C}$ polymorphisms of the RAD51 gene. The distribution of such haplotypes is shown in Table 4 . We did not find any correlation between haplotypes of both polymorphisms and the occurrence of $\mathrm{KC}$ and FECD.

\section{Discussion}

Several studies have confirmed that genetic factors play a pivotal role in corneal diseases development, as indicated by the association of such diseases with genetic syndromes or genetic disorders, segregation analyses, genetic epidemiological data, and gene mapping studies [5, 75-77]. Because DNA damage may be associated with development of the degenerative diseases, it was hypothesized that genes involved in DNA repair may influence an individual's susceptibility to these diseases [78, 79]. Increasing evidence has shown that genetic polymorphisms in DNA repair genes could modulate DNA repair capacity, resulting in DNA damage accumulation, and have an effect on the sensitivity of the organism to environmental mutagens [80-84], and then they contribute to some complex disorders, including corneal diseases $[59-62,85]$. Given the potential roles of the c.-61G>T and c. $-98 \mathrm{G}>\mathrm{C}$ polymorphisms of the RAD51 gene in the DNA repair, we examined the association between these two SNPs and $\mathrm{KC} / \mathrm{FECD}$ occurrence.

The RAD51 gene (full name: RAD51 homolog (S. cerevisiae); gene ID: 5888, also known as ECA, BRCC5, MRMV2, HRAD51, RAD51A, HsRad51, and HsT16930) is a eukaryotic homologue of Rad51 Saccharomyces cerevisiae. This gene consists of 16 exons spanning a region $>30 \mathrm{~kb}$ and encodes a 339 amino acid protein. The first exon and part of the second exon of RAD51 are located at its $5^{\prime}$ untranslated region (5' UTR), which may regulate gene expression [86]. The protein encoded by this gene is a member of the RAD51 protein family, which is known to be involved in homologous recombination and DNA repair [87]. Homologous recombination repair is a crucial DNA repair pathway to the maintenance of genomic stability. HRR repairs damaged DNA by identifying a stretch of homologous sequence on an undamaged sister chromatid, using that chromatid as a template for reconstruction of the broken DNA strands. One of the first steps during HRR is recognition of DSBs by the MRN complex comprising MRE11, RAD50, and NBS1 proteins. The central HRR protein-RAD51 recognizes the homology, forms a nucleoprotein filament with the $3^{\prime}$ ssDNA 
overhangs of the resected DSB and catalyzes homologous pairing and strand exchange [88]. RAD51 can interact with BRCA1 and BRCA2, which may be important for the cellular response to DNA damage. It was shown that BRCA2 regulates both the intracellular localization and DNA-binding ability of the RAD51 [89-92]. RAD51 knockout mouse (RAD51 ${ }^{-/-}$) show early embryonic lethality, suggesting that the RAD51 is fundamental for HRR and genomic integrity [93]. It has been demonstrated that loss of RAD51 expression predisposes cells to chromosome breaks or aberrations, mutagenesis, and cell death [94]. In general, even minor changes or deregulation of RAD51 may lead to genetic instability and cancer $[95,96]$.

The human RAD51 gene is highly polymorphic, at least its 733 SNPs have been registered in the public domain of the National Center for Biotechnology Information the Single Nucleotide Polymorphisms database (NCBI dbSNP; http://www.ncbi.nlm.nih.gov/snp). Among them, c.-61G $>\mathrm{T}$ (rs1801321; 172G $>$ T) and c. $-98 \mathrm{G}>\mathrm{C}(\mathrm{rs} 1801320 ; 135 \mathrm{G}>\mathrm{C})$ belong to the most common polymorphisms and are located at $5^{\prime}$ UTR. Interestingly, only a few SNPs are located in the coding region of this gene, none of which has a minor allele frequency $(\mathrm{MAF})>5 \%$, indicating that its protein structure is well conserved $[86,97]$. Only a few studies have investigated the association between the c.-61G $>\mathrm{T}$ polymorphisms and risk of cancer. In a large European case-control study of 2205 patients with breast cancer and 1805 controls, the c.$61 \mathrm{~T}$ variant genotypes were found to be associated with nonsignificantly reduced risk of breast cancer [98]. Another case-control study conducted in Korea also brought similar results [99]. As shown by bioinformatics analysis, c.-61T allele is located in a binding site for the transcription factor P300/CBP, a cofactor of nuclear receptor signaling that processes strong histone acetyltransferase activities and functions as an adaptor protein that enhances transcription of the genes to which the ligand is bound [100]. In contrast, the c.61G allele does not form a binding site of cis-transcriptional elements for P300/CBP. Thus, the presence of the T allele shows a greater effect on RAD51 gene expression. In another study, using luciferase reporter gene assay, it was shown that the c.61T allele was associated with a significantly higher activity of the RAD51 promoter as compared with the c.$61 \mathrm{G}$ allele [70]. As mentioned, the c.- $98 \mathrm{G}>\mathrm{C}$ polymorphism is also located at $5^{\prime} U T R$. Although functional consequence of this variation is unknown, it is speculated that because it alters a CpG island pattern in the promoter, it may regulate expression and affect mRNA levels [70, 101]. Case-control studies have shown that the c.-98C allele was associated with a 2 -fold lower risk of breast and ovarian cancer than the c.-98G allele, in BRCA1 5382insC mutation carriers [102] and other mutation carriers [103], whereas no association was found in studies of sporadic breast cancer [104, 105].

The effect of genetic variations in the RAD51 gene on the corneal endothelial cells has not yet been examined, so we chose the c.-61G>T and c.-98G>C SNPs to study in our research. We observed that the occurrence of $\mathrm{KC}$ was positively correlated with the G/G and G/T genotype and the $\mathrm{T}$ allele of the c.-61G>T SNP. In the case of the other polymorphism, c.-98G $>$ C, we did not find any correlation between genotypes/alleles and the occurrence of KC. We also found that the $\mathrm{G} / \mathrm{G}$ genotype and the $\mathrm{G}$ allele of the c.-98G $>C$ polymorphism decreased FECD occurrence, while the G/C genotype and the $\mathrm{C}$ allele increased it. Furthermore, the presence of the T/T genotype and the $\mathrm{T}$ allele of the c. $-61 \mathrm{G}>\mathrm{T}$ polymorphism was associated with a decreased occurrence of $\mathrm{KC}$, but on the other hand the G/T genotype increased it.

In summary, our results showed that the c.-61G $>\mathrm{T}$ and c. $-98 \mathrm{G}>\mathrm{C}$ SNPs of the RAD51 gene may be associated with individual susceptibility to keratoconus and Fuchs endothelial corneal dystrophy and suggested that DNA damage may be involved in the pathogenesis of these diseases.

\section{Conclusion}

This study suggests that the c.-61T/T and c.- $98 \mathrm{G}>\mathrm{C}$ polymorphisms of the RAD51 gene may play a role in KC and FECD pathogenesis and are considered as markers in these diseases, but further studies in other independent cohorts are needed to confirm or exclude these associations.

\section{Conflict of Interests}

The authors report that they have no conflict of interests.

\section{Acknowledgments}

This study was supported by Grant nos. N N402 591840 and N N402 591940 of the Polish Ministry of Science and Higher Education.

\section{References}

[1] Eye Banking Statistical Report, Eye Bank Association of America, Washington, DC, USA, 2008.

[2] Y. S. Rabinowitz, "Keratoconus," Survey of Ophthalmology, vol. 42, no. 4, pp. 297-319, 1998.

[3] B. A. Fink, L. T. Sinnott, H. Wagner, C. Friedman, and K. Zadnik, "The influence of gender and hormone status on the severity and progression of keratoconus," Cornea, vol. 29, no. 1, pp. 65-72, 2010.

[4] T. Georgiou, C. L. Funnell, A. Cassels-Brown, and R. O'Conor, "Influence of ethnic origin on the incidence of keratoconus and associated atopic disease in Asians and white patients," Eye, vol. 18, no. 4, pp. 379-383, 2004.

[5] Y. Wang, Y. S. Rabinowitz, J. I. Rotter, and H. Yang, "Genetic epidemiological study of keratoconus: evidence for major gene determination," American Journal of Medical Genetics, vol. 93, pp. 403-409, 2000.

[6] A. Hameed, S. Khaliq, M. Ismail et al., "A novel locus for Leber congenital amaurosis (LCA4) with anterior keratoconus mapping to chromosome 17p13," Investigative Ophthalmology and Visual Science, vol. 41, no. 3, pp. 629-633, 2000.

[7] S. Z. Walsh, "Keratoconus and blindness in 469 institutionalised subjects with Down syndrome and other causes of mental retardation," Journal of Mental Deficiency Research, vol. 25, no. 4, pp. 243-251, 1981.

[8] B. S. Kuming and L. Joffe, "Ehlers-Danlos syndrome associated with keratoconus: a case report," South African Medical Journal, vol. 52, no. 10, pp. 403-405, 1977. 
[9] E. G. Woodward and M. T. Morris, "Joint hypermobility in keratoconus," Ophthalmic and Physiological Optics, vol. 10, no. 4, pp. 360-362, 1990.

[10] M. Macsai, E. Maguen, and P. Nucci, "Keratoconus and Turner's syndrome," Cornea, vol. 16, no. 5, pp. 534-536, 1997.

[11] J. Parker, W. W. Ko, G. Pavlopoulos, P. J. Wolfe, Y. S. Rabinowitz, and S. T. Feldman, "Videokeratography of keratoconus in monozygotic twins," Journal of Refractive Surgery, vol. 12, no. 1, pp. 180-183, 1996.

[12] A. E. Hughes, D. P. Dash, A. J. Jackson, D. G. Frazer, and G. Silvestri, "Familial keratoconus with cataract: linkage to the long arm of chromosome 15 and exclusion of candidate genes," Investigative Ophthalmology and Visual Science, vol. 44, no. 12, pp. 5063-5066, 2003.

[13] F. Brancati, E. M. Valente, A. Sarkozy et al., "A locus for autosomal dominant keratoconus maps to human chromosome 3p14-q13," Journal of Medical Genetics, vol. 41, no. 3, pp. 188-192, 2004.

[14] Y. G. Tang, Y. S. Rabinowitz, K. D. Taylor et al., "Genomewide linkage scan in a multigeneration Caucasian pedigree identifies a novel locus for keratoconus on chromosome 5q14.3-q21.1," Genetics in Medicine, vol. 7, no. 6, pp. 397-405, 2005.

[15] X. Li, Y. S. Rabinowitz, Y. G. Tang et al., "Two-stage genomewide linkage scan in keratoconus sib pair families," Investigative Ophthalmology and Visual Science, vol. 47, no. 9, pp. 3791-3795, 2006.

[16] B. Jafri, H. Lichter, and R. D. Stulting, "Asymmetric keratoconus attributed to eye rubbing," Cornea, vol. 23, no. 6, pp. 560-564, 2004.

[17] J. T. Barr, B. S. Wilson, M. O. Gordon et al., "Estimation of the incidence and factors predictive of corneal scarring in the Collaborative Longitudinal Evaluation of Keratoconus (CLEK) study," Cornea, vol. 25, no. 1, pp. 16-25, 2006.

[18] S. E. Wilson and W. M. Bourne, "Fuchs' dystrophy," Cornea, vol. 7, no. 1, pp. 2-18, 1988.

[19] A. P. Adamis, V. Filatov, B. J. Tripathi, and R. C. Tripathi, "Fuchs' endothelial dystrophy of the cornea," Survey of Ophthalmology, vol. 38, no. 2, pp. 149-168, 1993.

[20] H. K. L. Yuen, C. E. Rassier, M. S. R. Jardeleza et al., "A morphologic study of Fuchs dystrophy and bullous keratopathy," Cornea, vol. 24, no. 3, pp. 319-327, 2005.

[21] Q. J. Li, M. F. Ashraf, D. Shen et al., "The role of apoptosis in the pathogenesis of Fuchs endothelial dystrophy of the cornea," Archives of Ophthalmology, vol. 119, no. 11, pp. 1597-1604, 2001.

[22] K. H. Baratz, N. Tosakulwong, E. Ryu et al., "E2-2 protein and Fuchs's corneal dystrophy," New England Journal of Medicine, vol. 363, no. 11, pp. 1016-1024, 2010.

[23] G. O. Waring III, W. M. Bourne, H. F. Edelhauser, and K. R. Kenyon, "The corneal endothelium. Normal and pathologic structure and function," Ophthalmology, vol. 89, no. 6, pp. 531590, 1982.

[24] A. O. Eghrari and J. D. Gottsch, "Fuchs corneal dystrophy," Expert Review of Ophthalmology, vol. 5, no. 2, pp. 147-159, 2010.

[25] H. Elhalis, B. Azizi, and U. V. Jurkunas, "Fuchs endothelial corneal dystrophy," Ocular Surface, vol. 8, no. 4, pp. 173-184, 2010.

[26] J. D. Gottsch, O. H. Sundin, S. H. Liu et al., "Inheritance of a novel COL8A2 mutation defines a distinct early-onset subtype of fuchs corneal dystrophy," Investigative Ophthalmology and Visual Science, vol. 46, no. 6, pp. 1934-1939, 2005.

[27] N. A. Afshari, A. B. Pittard, A. Siddiqui, and G. K. Klintworth, "Clinical study of fuchs corneal endothelial dystrophy leading to penetrating keratoplasty: a 30-year experience," Archives of Ophthalmology, vol. 124, no. 6, pp. 777-780, 2006.

[28] P. Rosenblum, W. J. Stark, and I. H. Maumenee, "Hereditary Fuch's dystrophy," American Journal of Ophthalmology, vol. 90, no. 4, pp. 455-462, 1980.

[29] S. Biswas, F. L. Munier, J. Yardley et al., "Missense mutations in COL8A2, the gene encoding the $\alpha 2$ chain of type VIII collagen, cause two forms of corneal endothelial dystrophy," Human Molecular Genetics, vol. 10, no. 21, pp. 2415-2423, 2001.

[30] G. K. Klintworth, "Corneal dystrophies," Orphanet Journal of Rare Diseases, vol. 4, no. 1, article 7, 2009.

[31] J. H. Krachmer, J. J. Purcell Jr., C. W. Young, and K. D. Bucher, "Corneal endothelial dystrophy. A study of 64 families," Archives of Ophthalmology, vol. 96, no. 11, pp. 2036-2039, 1978.

[32] J. D. Gottsch, C. Zhang, O. H. Sundin, W. R. Bell, W. J. Stark, and W. R. Green, "Fuchs corneal dystrophy: aberrant collagen distribution in an L450W Mutant of the COL8A2 gene," Investigative Ophthalmology and Visual Science, vol. 46, no. 12, pp. 4504-4511, 2005.

[33] P. Liskova, Q. Prescott, S. S. Bhattacharya, and S. J. Tuft, "British family with early-onset Fuchs' endothelial corneal dystrophy associated with p.L450W mutation in the COL8A2 gene," British Journal of Ophthalmology, vol. 91, no. 12, pp. 1717-1718, 2007.

[34] J.-W. Mok, H.-S. Kim, and C.-K. Joo, "Q455V mutation in COL8A2 is associated with Fuchs' corneal dystrophy in Korean patients," Eye, vol. 23, no. 4, pp. 895-903, 2009.

[35] O. H. Sundin, A. S. Jun, K. W. Broman et al., "Linkage of late-onset fuchs corneal dystrophy to a novel locus at 13pTel13q12.13," Investigative Ophthalmology and Visual Science, vol. 47, no. 1, pp. 140-145, 2006.

[36] S. A. Riazuddin, A. O. Eghrari, A. Al-Saif et al., "Linkage of a mild late-onset phenotype of fuchs corneal dystrophy to a novel locus at 5q33.1-q35.2," Investigative Ophthalmology and Visual Science, vol. 50, no. 12, pp. 5667-5671, 2009.

[37] S. A. Riazuddin, E. N. Vithana, L.-F. Seet et al., "Missense mutations in the sodium borate cotransporter SLC4A11 cause late-onset Fuchs corneal dystrophya," Human Mutation, vol. 31, no. 11, pp. 1261-1268, 2010.

[38] T. D. Gondhowiardjo, N. J. Van Haeringen, H. J. Volker-Dieben et al., "Analysis of corneal aldehyde dehydrogenase patterns in pathologic corneas," Cornea, vol. 12, no. 2, pp. 146-154, 1993.

[39] T. D. Gondhowiardjo and N. J. Van Haeringen, "Corneal aldehyde dehydrogenase, glutathione reductase, and glutathione Stransferase in pathologic corneas," Cornea, vol. 12, no. 4, pp. 310-314, 1993.

[40] A. Behndig, K. Karlsson, B. O. Johansson, T. Brännström, and S. L. Marklund, "Superoxide dismutase isoenzymes in the normal and diseased human cornea," Investigative Ophthalmology and Visual Science, vol. 42, no. 10, pp. 2293-2296, 2001.

[41] R. Buddi, B. Lin, S. R. Atilano, N. C. Zorapapel, M. C. Kenney, and D. J. Brown, "Evidence of oxidative stress in human corneal diseases," Journal of Histochemistry and Cytochemistry, vol. 50, no. 3, pp. 341-351, 2002.

[42] M. C. Kenney, M. Chwa, S. R. Atilano et al., "Increased levels of catalase and cathepsin V/12 but decreased TIMP-1 in keratoconus corneas: evidence that oxidative stress plays a role in this disorder," Investigative Ophthalmology and Visual Science, vol. 46, no. 3, pp. 823-832, 2005.

[43] U. V. Jurkunas, I. Rawe, M. S. Bitar et al., "Decreased expression of peroxiredoxins in Fuchs' endothelial dystrophy," Investigative 
Ophthalmology and Visual Science, vol. 49, no. 7, pp. 2956-2963, 2008.

[44] U. V. Jurkunas, M. S. Bitar, T. Funaki, and B. Azizi, "Evidence of oxidative stress in the pathogenesis of fuchs endothelial corneal dystrophy," American Journal of Pathology, vol. 177, no. 5, pp. 2278-2289, 2010.

[45] E. Arnal, C. Peris-Martínez, J. L. Menezo, S. Johnsen-Soriano, and F. J. Romero, "Oxidative stress in keratoconus?" Investigative Ophthalmology \& Visual Science, vol. 52, no. 12, pp. 85928597, 2011.

[46] J. Wenk, P. Brenneisen, C. Meewes et al., "UV-induced oxidative stress and photoaging," Current Problems in Dermatology, vol. 29, pp. 83-94, 2001.

[47] H. Pelicano, D. Carney, and P. Huang, "ROS stress in cancer cells and therapeutic implications," Drug Resistance Updates, vol. 7, no. 2, pp. 97-110, 2004.

[48] G. L. Squadrito and W. A. Pryor, "Oxidative chemistry of nitric oxide: the roles of superoxide, peroxynitrite, and carbon dioxide," Free Radical Biology and Medicine, vol. 25, no. 4-5, pp. 392-403, 1998.

[49] S. R. Atilano, P. Coskun, M. Chwa et al., "Accumulation of mitochondrial DNA damage in keratoconus corneas," Investigative Ophthalmology and Visual Science, vol. 46, no. 4, pp. 1256-1263, 2005.

[50] P. H. Clingen, J. E. Lowe, and M. H. Green, "Measurement of DNA damage and repair capacity as a function of age using the comet assay," Methods in Molecular Medicine, vol. 38, pp. 143$157,2000$.

[51] J. Blasiak and J. P. Szaflik, "DNA damage and repair in agerelated macular degeneration," Frontiers in Bioscience, vol. 16, no. 4, pp. 1291-1301, 2011.

[52] J. Blasiak, S. Glowacki, A. Kauppinen, and K. Kaarniranta, "Mitochondrial and nuclear DNA damage and repair in agerelated macular degeneration," International Journal of Molecular Sciences, vol. 14, no. 2, pp. 2996-3010, 2013.

[53] K. Ma, L. Qiu, K. Mrasek et al., "Common fragile sites: genomic hotspots of DNA damage and carcinogenesis," International Journal of Molecular Sciences, vol. 13, no. 9, pp. 11974-11999, 2012.

[54] C. Canugovi, M. Misiak, L. K. Ferrarelli, D. L. Croteau, and V. A. Bohr, "The role of DNA repair in brain related disease pathology," DNA Repair, vol. 12, no. 8, pp. 578-587, 2013.

[55] K. Rothkamm, I. Krüger, L. H. Thompson, and M. Löbrich, "Pathways of DNA double-strand break repair during the mammalian cell cycle," Molecular and Cellular Biology, vol. 23, no. 16, pp. 5706-5715, 2003.

[56] J. H. J. Hoeijmakers, "Genome maintenance mechanisms for preventing cancer," Nature, vol. 411, no. 6835, pp. 366-374, 2001.

[57] D. C. Van Gent, J. H. J. Hoeijmakers, and R. Kanaar, "Chromosomal stability and the DNA double-stranded break connection," Nature Reviews Genetics, vol. 2, no. 3, pp. 196-206, 2001.

[58] A. Shoham, M. Hadziahmetovic, J. L. Dunaief, M. B. Mydlarski, and H. M. Schipper, "Oxidative stress in diseases of the human cornea," Free Radical Biology and Medicine, vol. 45, no. 8, pp. 1047-1055, 2008.

[59] C.-C. Chiang, Y.-Y. Tsai, D.-T. Bau et al., "Pterygium and genetic polymorphisms of the DNA repair enzymes XRCC1, XPA, and XPD," Molecular Vision, vol. 16, pp. 698-704, 2010.

[60] E. Görgün, M. Güven, M. Unal et al., "Polymorphisms of the DNA repair genes XPD and XRCC1 and the risk of age-related macular degeneration," Investigative Ophthalmology \& Visual Science, vol. 51, no. 9, pp. 4732-4737, 2010.
[61] G. Padma, M. Mamata, K. Ravi Kumar Reddy, and T. Padma, "Polymorphisms in two DNA repair genes (XPD and XRCC1)association with age related cataracts," Molecular Vision, vol. 17, pp. 127-133, 2011.

[62] S. Yousaf, M. I. Khan, S. Micheal et al., "XRCC1 and XPD DNA repair gene polymorphisms: a potential risk factor for glaucoma in the Pakistani population," Molecular Vision, vol. 17, pp. 11531163, 2011.

[63] K. Zhang, B. Zhou, Y. Wang, L. Rao, and L. Zhang, "The XRCC1 Arg280His polymorphism contributes to cancer susceptibility: an update by meta-analysis of 53 individual studies," Gene, vol. 510, no. 2, pp. 93-101, 2012.

[64] N. Udar, S. R. Atilano, D. J. Brown et al., "SOD1: a candidate gene for keratoconus," Investigative Ophthalmology and Visual Science, vol. 47, no. 8, pp. 3345-3351, 2006.

[65] M. Stabuc-Silih, M. Ravnik-Glavac, D. Glavac, M. Hawlina, and M. Strazisar, "Polymorphisms in COL4A3 and COL4A4 genes associated with keratoconus," Molecular Vision, vol. 15, pp. 2848-2860, 2009.

[66] K. P. Burdon, S. Macgregor, Y. Bykhovskaya et al., "Association of polymorphisms in the hepatocyte growth factor gene promoter with keratoconus," Investigative Ophthalmology \& Visual Science, vol. 52, no. 11, pp. 8514-8519, 2011.

[67] M. Czugala, J. A. Karolak, D. M. Nowak et al., "Novel mutation and three other sequence variants segregating with phenotype at keratoconus 13q32 susceptibility locus," European Journal of Human Genetics, vol. 20, no. 4, pp. 389-397, 2012.

[68] T. Guan, C. Liu, Z. Ma, and S. Ding, “The point mutation and polymorphism in keratoconus candidate gene TGFBI in Chinese population," Gene, vol. 503, pp. 137-139, 2012.

[69] R. P. Igo Jr., L. J. Kopplin, and P. Joseph, "Differing roles for TCF 4 and COL8A2 in central corneal thickness and fuchs endothelial corneal dystrophy," PLoS ONE, vol. 7, no. 10, Article ID e46742, 2012.

[70] L. Hasselbach, S. Haase, D. Fischer, H.-C. Kolberg, and H.W. Stürzbecher, "Characterisation of the promoter region of the human DNA-repair gene Rad51," European Journal of Gynaecological Oncology, vol. 26, no. 6, pp. 589-598, 2005.

[71] S. C. Pflugfelder, Z. Liu, W. Feuer, and A. Verm, "Corneal thickness indices discriminate between keratoconus and contact lens-induced corneal thinning," Ophthalmology, vol. 109, no. 12, pp. 2336-2341, 2002.

[72] J. T. Holladay, "Keratoconus detection using corneal topography," Journal of Refractive Surgery, vol. 25, no. 10, pp. S958-S962, 2009.

[73] J. P. Szaflik, "Comparison of in vivo confocal microscopy of human cornea by white light scanning slit and laser scanning systems," Cornea, vol. 26, no. 4, pp. 438-445, 2007.

[74] J. S. Weiss, H. U. Møller, W. Lisch et al., "The IC3D classification of the corneal dystrophies," Cornea, vol. 27, no. 2, pp. -S42-S83, 2008.

[75] M. Edwards, C. N. J. McGhee, and S. Dean, "The genetics of keratoconus," Clinical and Experimental Ophthalmology, vol. 29, no. 6, pp. 345-351, 2001.

[76] Y. Lu, V. Vitart, K. P. Burdon et al., "Genome-wide association analyses identify multiple loci associated with central corneal thickness and keratoconus," Nature Genetics, vol. 45, no. 2, pp. 155-163, 2013.

[77] K. P. Burdon and A. L. Vincent, "Insights into keratoconus from a genetic perspective," Clinical and Experimental Optometry, vol. 96, no. 2, pp. 146-154, 2013. 
[78] Y. Murakami, Y. Ikeda, N. Yoshida et al., "MutT homolog-1 attenuates oxidative DNA damage and delays photoreceptor cell death in inherited retinal degeneration," American Journal of Pathology, vol. 181, no. 4, pp. 1378-1386, 2012.

[79] P. Ramos-Espinosa, E. Rojas, and M. Valverde, "Differential DNA damage response to UV and hydrogen peroxide depending of differentiation stage in a neuroblastoma model," Neurotoxicology, vol. 33, no. 5, pp. 1086-1095, 2012.

[80] A. G. Raetz, Y. Xie, S. Kundu, M. K. Brinkmeyer, C. Chang, and S. S. David, "Cancer-associated variants and a common polymorphism of MUTYH exhibit reduced repair of oxidative DNA damage using a GFP-based assay in mammalian cells," Carcinogenesis, vol. 33, no. 11, pp. 2301-2309, 2012.

[81] A. Gdowicz-Klosok, M. Widel, and J. Rzeszowska-Wolny, “The influence of XPD, APE1, XRCC1, and NBS1 polymorphic variants on DNA repair in cells exposed to X-rays," Mutation Research, 2013.

[82] J. Pérez-Mayoral, A. L. Pacheco-Torres, L. Morales, H. AcostaRodríguez, J. L. Matta, and J. Dutil, "Genetic polymorphisms in RAD23B and XPC modulate DNA repair capacity and breast cancer risk in Puerto Rican women," Molecular Carcinogenesis, 2013.

[83] V. Simonelli, S. Camerini, F. Mazzei et al., "Genotype-phenotype analysis of S326C OGG1 polymorphism: a risk factor for oxidative pathologies," Free Radical Biology \& Medicine, 2013.

[84] L. E. Wang, O. Y. Gorlova, J. Ying et al., "Genome-wide association study reveals novel genetic determinants of DNA repair capacity in lung cancer," Cancer Research, vol. 73, no. 1, pp. 256$264,2013$.

[85] M. Ünal, M. Güven, B. Batar, A. Özaydin, A. Sarici, and K. Devranoğlu, "Polymorphisms of DNA repair genes XPD and XRCC1 and risk of cataract development," Experimental Eye Research, vol. 85, no. 3, pp. 328-334, 2007.

[86] J. Lu, L.-E. Wang, P. Xiong, E. M. Sturgis, M. R. Spitz, and Q. Wei, " $172 \mathrm{G}<\mathrm{T}$ variant in the $5^{\prime}$ untranslated region of DNA repair gene RAD51 reduces risk of squamous cell carcinoma of the head and neck and interacts with a P53 codon 72 variant," Carcinogenesis, vol. 28, no. 5, pp. 988-994, 2007.

[87] L. H. Thompson and D. Schild, "Recombinational DNA repair and human disease," Mutation Research, vol. 509, no. 1-2, pp. 4978, 2002.

[88] S. P. Jackson, "Sensing and repairing DNA double-strand breaks," Carcinogenesis, vol. 23, no. 5, pp. 687-696, 2002.

[89] A. A. Davies, J.-Y. Masson, M. J. McIlwraith et al., "Role of BRCA2 in control of the RAD51 recombination and DNA repair protein," Molecular Cell, vol. 7, no. 2, pp. 273-282, 2001.

[90] A. R. Venkitaraman, "Functions of BRCA1 and BRCA2 in the biological response to DNA damage," Journal of Cell Science, vol. 114, no. 20, pp. 3591-3598, 2001.

[91] K. Gudmundsdottir and A. Ashworth, "The roles of BRCA1 and BRCA2 and associated proteins in the maintenance of genomic stability," Oncogene, vol. 25, no. 43, pp. 5864-5874, 2006.

[92] O. S. Gildemeister, J. M. Sage, and K. L. Knight, "Cellular redistribution of Rad51 in response to DNA damage: novel role for Rad51C," Journal of Biological Chemistry, vol. 284, no. 46, pp. 31945-31952, 2009.

[93] T. Tsuzuki, Y. Fujii, K. Sakumi et al., "Targeted disruption of the Rad51 gene leads to lethality in embryonic mice," Proceedings of the National Academy of Sciences of the United States of America, vol. 93, no. 13, pp. 6236-6240, 1996.
[94] E. Sonoda, M. S. Sasaki, J.-M. Buerstedde et al., "Rad51-deficient vertebrate cells accumulate chromosomal breaks prior to cell death," EMBO Journal, vol. 17, no. 2, pp. 598-608, 1998.

[95] C. Richardson, "RAD51, genomic stability, and tumorigenesis," Cancer Letters, vol. 218, no. 2, pp. 127-139, 2005.

[96] J. Thacker, "The RAD51 gene family, genetic instability and cancer," Cancer Letters, vol. 219, no. 2, pp. 125-135, 2005.

[97] W. James Kent, C. W. Sugnet, T. S. Furey et al., "The human genome browser at UCSC," Genome Research, vol. 12, no. 6, pp. 996-1006, 2002.

[98] B. Kuschel, A. Auranen, S. McBride et al., "Sex differences in sex chromosome gene expression in mouse brain," Human Molecular Genetics, vol. 11, no. 12, pp. 1409-1419, 2002.

[99] K.-M. Lee, J.-Y. Choi, C. Kang et al., "Genetic polymorphisms of selected DNA repair genes, estrogen and progesterone receptor status, and breast cancer risk," Clinical Cancer Research, vol. 11, no. 12, pp. 4620-4626, 2005.

[100] D. Chekravarti, V. J. LaMorte, M. C. Nelson et al., "Role of CBP/P300 in nuclear receptor signalling," Nature, vol. 383, no. 6595, pp. 99-103, 1996.

[101] A. C. Antoniou, O. M. Sinilnikova, J. Simard et al., "RAD51 $135 \mathrm{G} \rightarrow \mathrm{C}$ modifies breast cancer risk among BRCA2 mutation carriers: results from a combined analysis of 19 studies," American Journal of Human Genetics, vol. 81, no. 6, pp. 1186-1200, 2007.

[102] A. Jakubowska, S. A. Narod, D. E. Goldgar et al., "Breast cancer risk reduction associated with the RAD51 polymorphism among carriers of the BRCA1 5382insC mutation in Poland," Cancer Epidemiology Biomarkers and Prevention, vol. 12, no. 5, pp. 457-459, 2003.

[103] M. E. Sehl, L. R. Langer, J. C. Papp et al., "Associations between single nucleotide polymorphisms in double- stranded DNA repair pathway genes and familial breast cancer," Clinical Cancer Research, vol. 15, no. 6, pp. 2192-2203, 2009.

[104] J. Blasiak, K. Przybyłowska, A. Czechowska et al., "Analysis of the G/C polymorphism in the $5^{\prime}$-untranslated region of the RAD51 gene in breast cancer," Acta Biochimica Polonica, vol. 50, no. 1, pp. 249-253, 2003.

[105] M. A. Loizidou, T. Michael, S. L. Neuhausen et al., "DNA-repair genetic polymorphisms and risk of breast cancer in Cyprus," Breast Cancer Research and Treatment, vol. 115, no. 3, pp. 623627, 2009. 


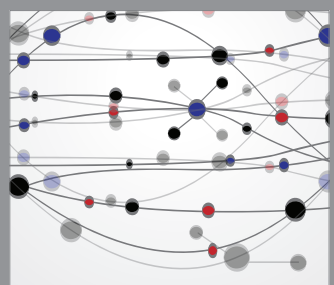

The Scientific World Journal
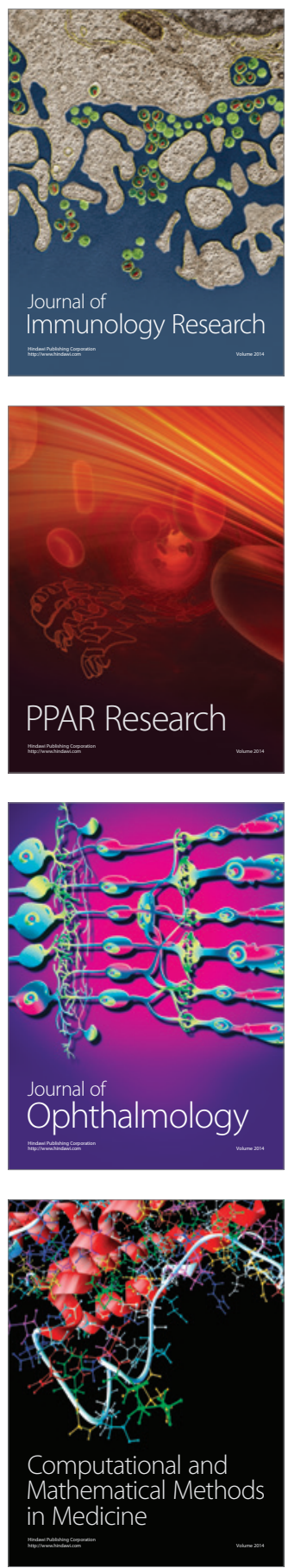

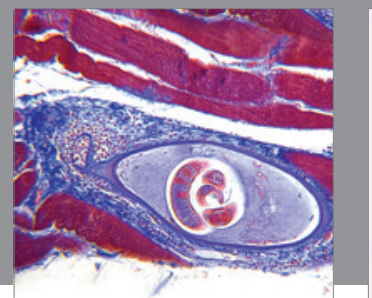

Gastroenterology

Research and Practice
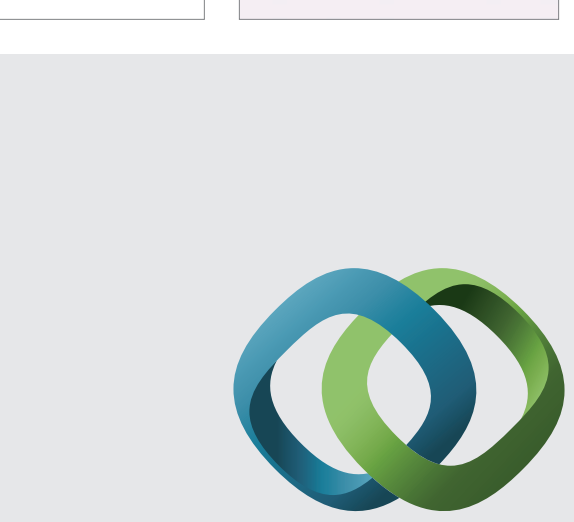

\section{Hindawi}

Submit your manuscripts at

http://www.hindawi.com
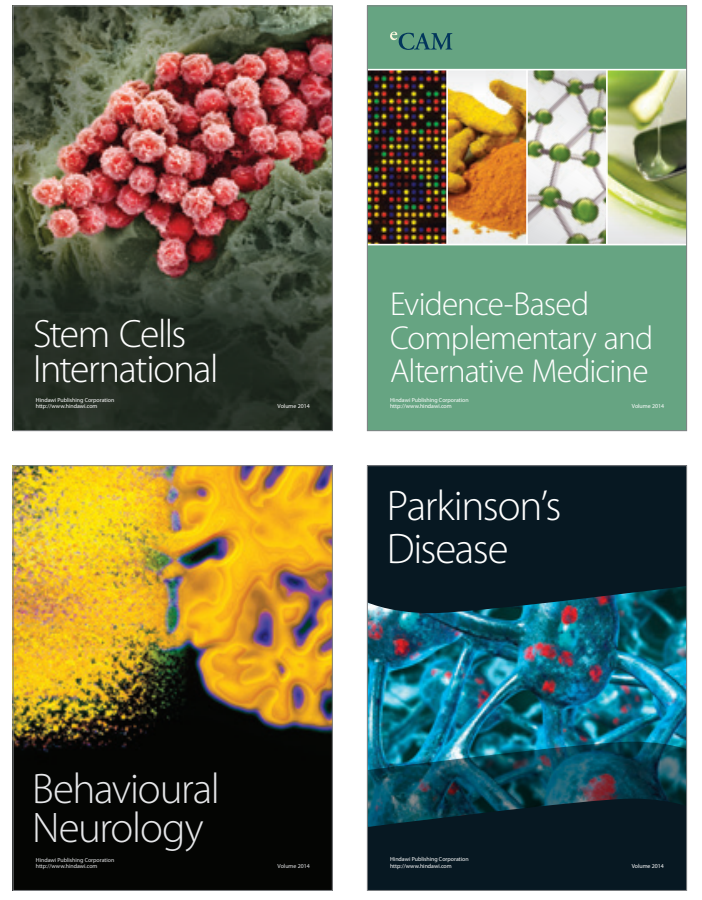
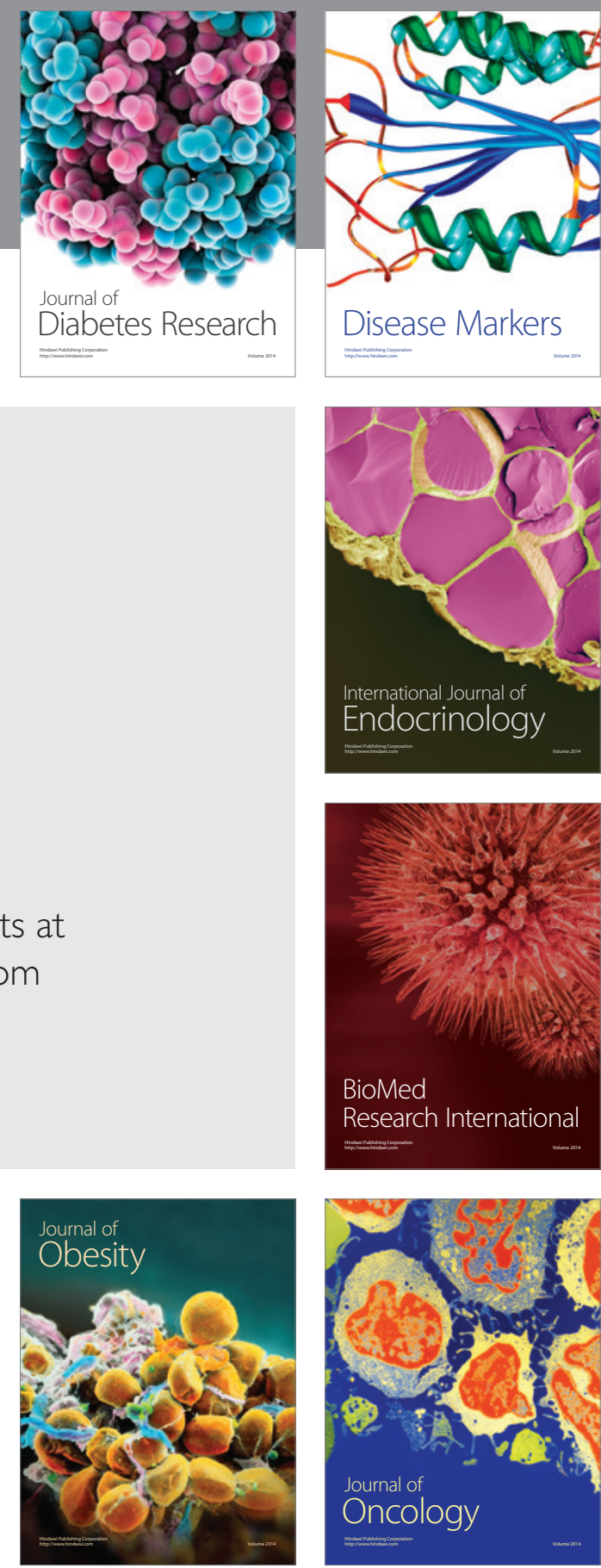

Disease Markers
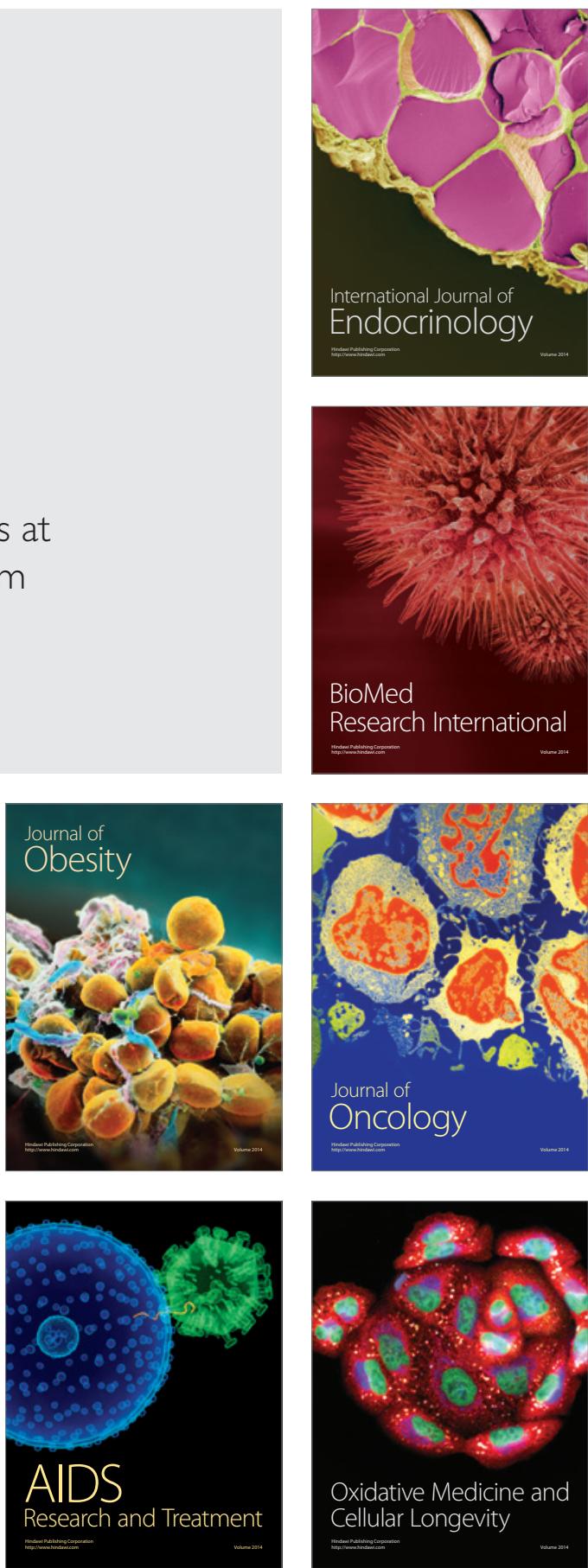